Vol. 3, No. 1, March 2021 e-ISSN: 2656-4882 p-ISSN: 2656-5935

\title{
Correlational Analysis of the Availability and Usage of Geographic Information Systems by Students and Lecturers an Higher Educational Institutions
}

\author{
Osakwe Jude ${ }^{1}$ Ujakpa Martin², Ankome Teresia ${ }^{3}$ \\ ${ }_{1,3}$ Department of Informatics, Namibia University of Science and Technology \\ ${ }^{3}$ Department of Information Technology. International University of Management, Windhoek, \\ Namibia \\ Email: 1jdosakwe@yahoo.com, ${ }^{2 u j a k p a m a b e i f a m @ g m a i l . c o m, ~}{ }^{3}$ tankome@nust.na
}

\begin{abstract}
There has been a rapid development of Information and Communication Technologies (ICTs) globally, and this includes the Geographic Information Systems (GISs) which has evolved over the years and aimed at solving many geographic problems as fast and efficiently as possible. The importance of GIS to students and lecturers in higher educational institutions is its ability to easily analyze locations together with the conventional database systems. This paper assessed the correlation between the availability and use of GIS in Higher Educational Institutions (HEIs). The study is exploratory and employed the use of questionnaires as an instrument to collect data. Simple random sampling technique was used to select one hundred and ten (110) lecturers' one thousand five hundred and seventy-nine (1579) students from a university. Findings revealed that GIS for analysis is still at its lowest ebb and hence calls for action to motivate or encourage lecturers and students to use it. Though there are indications that GIS will be of great value in schools, students and lecturers they will be happy to use it for their teaching and learning. The study also revealed the availability of GIS was not tied to its usage.
\end{abstract}

Keywords: GIS, Technology, Education, Higher Educational Institutions

\section{INTRODUCTION}

The availability of technological facilities and resources if widely utilized in everyday life, as well as in workplaces will enhance social development. Institutions must assess and utilize ICT to understand their learning environments as well as their professional lives (Aharony \& Shonfield, 2015). As attention is being shifted to the 21 st-century innovative skills, there must be an expansion to programmes that are related to the diverse and sophisticated ways of carrying out activities to accommodate all forms of societal values. In today's emerging technologies, one of the most conspicuous and important contributors to society is the Geographic or Geospatial Information System (GIS). The geospatial angle of information system is mainly the visual aspect of data through maps to facilitate interaction, communication and discussion among various stakeholders. GIS creates 
geographic maps through the use of software that can integrate spatial data (e.g., geo-referenced coordinates such as latitude and longitude) and non-spatial data.

According to Bearman, et. al., (2016), the advent of GIS has led to the tremendous improvement in spatial decision making particularly in the education sector. This is possible through the combination of spatial data sets of different referencing systems to allow for effective and efficient manipulation and analysis in a computer environment. Some important justifications for the introduction of GIS in education have been outlined by Delparte, Richardson, Eitel, Matsaw, \& Cohn, 2016. Delparte et. al., (2016 p.4), described GIS in education as an "educative tool that enhances student's spatial thinking skills and also as workplace skills as a needed tool for future knowledge in geospatial technologies". Furthermore, educators have used geospatial technologies to improve the classroom teaching and learning environment which may, according to Stonier \& Hong (2016), depend on the innovative technology in institutions of learning. Nevertheless, Ngwu (2014), also mentioned non availability of ICT resources in schools as a challenge to the use of GIS for pedagogy. This, therefore, indicates that, even though teachers are adequately trained and willing to impart the knowledge to students, they are unable to do so due to lack of technological facilities.

Functionally, GIS is a dynamic process allowing the data and map to be updated automatically. It enables the students to visualise and analyse spatial information in an innovative way that exposes hitherto hidden relationships, patterns and developments or trends. In this modern-day, where technology is a fast-growing, GIS is seen as the core of all contemporary spatial decision making that may be in the areas of location identification, public service, planning/environmental planning. Notwithstanding the significant part it plays in government and society, it's the role in education till date is very negligible (Blank et al., 2016). Though its application in schools and universities has already witnessed a progressive development, it has happened at a very slow speed. This is largely due to underutilisation and availability of GIS which ultimately affects the usage pattern (Mkhongi \& Musakwa, 2020; Aliyu, 2011 and Eguavon \& Adeyemi, 2012). This paper, therefore, analysed the relationship between the availability and the usage of GIS by students and lecturers in higher institutions.

\subsection{Research Objectives}

The study aimed at ascertaining the availability of Geographic information system and its effect on usage in higher institutions. The aim of the study was achieved by exploring the availability of GIS, assessing its usage pattern and ascertaining the relationship between the availability and usage in a University setting. 


\subsection{Related literature}

Geographic information is knowledge about what is, where, when and where. According to Catlin (2012), it is "a technological field that incorporates geographical features with tabular data to map, analyse, and assess real-world problems". GIS can incorporate spatial data together with attribute data of features they represent. One of the characteristics of GIS is its ability to support decision-making in a various government establishment, educational and research organizations over the years. It is worthy to note that GIS is being taught across a wide range of professional disciplines now than previously done as previously limited to geography and environmental science (Bearman et. al., 2015).

Johnson and Pellikka, (2005), noted that "GIS was originally developed for scientific land management purposes in Canada during the 1960s during which Canada Geographic Information System was established for the collection and analysis of land use data and the production of statistics for land use management plan". Since then, GIS has been typically used as an innovative tool that provides a highly significant improvement in presentation, preparation and flexibility to micro-planning to justify the benefits (Lindgren, 2017; Fan et al., Yu et al., 2019).

\subsection{GIS and Higher Education}

The emergence of computers has opened new prospects for GPS, RS, and Geographic information science. Information engineering is gradually collapsing into the GIS which encompasses the spatial information processing. The GIS which has gained a lot of ground is advantageous in the sense that it has opened new windows for information Engineering. It has the capacity for big data, big technology, big platform and big application.

In the education sector, GIS has a great impact as a tool for decision-making, policy formulation and pedagogy. In the area of administration, GIS can be useful to administrators. GIS can offer them a method to visualize monitor the campus. It can also be used to map the buildings on campus and also other infrastructural facilities. Furthermore, routing school buses can be made more meaningful through the use of GIS. It can also be an effective policy-making tool when it is used to present patterns in educational achievement and also to target new programmes (Korpilo et al., 2018; Barro et al., 2020; Kim et al., 2019; Muñoz et al., 2019; Jurado Rota et al., 2019). According to Soon et al., (2016), due to its content benefits, GIS education has attracted the attention of various schools in different countries globally and is seen as a very useful tool to analyze the schoolplanning situation. Moreover, making educational administration simple, expansion of compulsory education, enforcement of clear school planning policies, and the creation of the digital database that can be used in GIS, will have a more positive effect on the improvement of school services and qualities for the present and upcoming students. 


\subsection{Benefits of GIS in higher institutions.}

GIS tools can be used by students to study the content of different disciplines in humanities, arts and sciences. GIS allows students to explore content knowledge and shows how to think about the world (Soon et al., 2016), It can spur critical thinking among students through the use of real data to connect their communities and a variety of sets or locations. Students can use GIS to helps students to discover the relationships among "people, climate, land use, vegetation, river systems, aquifers, landforms, soils and natural hazards".

In teaching and instruction, GIS can integrate with fieldworks to help students in understanding and appreciating our world (Alibrandi \& Goldstein, 2015; Delparte, Richardson, Eitel, Matsaw, \& Cohn, 2016; Stonier \& Hong, 2016). Louv, (2005) also stated that "it opens students to attribute information with GPS such as locations tree species, historical buildings, water quality, and other variables on a field trip or even on their school or university campus". DeGrauwe (2002) identified areas in which GIS can aid education micro-planning. They are as follows:

- Data presentation is more attractive with the use of GIS than the traditional static maps.

- Projection of tabular data onto maps aids in identifying "unexpected" conditions which, now noticed, demands closer examination.

- When geographical (spatial) factors are considered, the analysis becomes "finer" and more accurate, increasing the possibility that resulting strategy will be more pertinent.

- More flexible assistance can be provided in prospective planning at multiple levels or units of analysis: national, regional, provincial/district, and local.

Hite (2008) noted that "school mapping as a technical exercise has become a relatively normalized and institutionalized practice in education's micro-planning". Similar findings were also reported by Aladag (2010); Demirci (2011); Favier and Van der Schee (2014); Goldstein and Alibrandi (2013); Kaya (2011); and (Blank, Almquist, Estrada, \& Crews, 2016; Delparte et al., 2016). In as much school mapping is a tabular, cartographical representation of a particular space or place, it also involves considering and including various kinds of technical data that impact and populate the physical and social context of analysis. As a process that produces explicit and efficient products, school mapping is fundamentally an educational micro-planning effort focused on increasing school resource efficiently and equitably through the effective use of the school curricular.

There are implications for GIS in school curricula towards its application for pedagogy. It develops spatial thinking through cognitive skills across numerous subjects in sciences, arts and humanities (NRC, 2006; Sinton \& Bednarz, 2007). According to Kerski, (2008), GIS provides a powerful platform for many types of 
learning. It facilitates spatial reasoning by driving the learner's thinking towards using the concepts of place and space.

Notable among the ways GIS can support pedagogy according to NRC (2006, page number) are:

- GIS is capable of can enabling the formulation of scientific problems and solutions.

- GIS can create a link between science and policy by solving a variety of problems in real-world contexts thereby serving as a tool for problem-solving and scientific research.

- GIS can facilitate learning across the school subjects and enhance learning from interdisciplinary and multidisciplinary perspectives.

- GIS can offer a rich, generative, inviting and challenging problem-solving environment to empower students for addressing significant issues (with the same tools that professionals use to address issues in their work).

- GIS has the potentiality for accommodating and accessing the full range of learners, including the visually impaired, differently able students and those with the difficulty of learning in traditional ways. It is also rigorous enough to challenge gifted students.

- GIS can be used effectively in diverse educational settings by infusing in the curriculum or using in traditional subject-based curricula of all grades. It also enables ranging modes of use such as the individual and stand-alone, collaborative and networked.

The above points depict the potential benefits of introducing GIS in schools as a teaching subject and also as a means of developing problem-solving skills which relate to complex issues in real-world contexts. Students who can solve problems by incorporating several sources of data into a visual presentation with GIS mapping will learn a way of describing their learning outcomes and engaging in community discourse and policy analysis, which in essence are the skills needed for the development of, and engagement in, a GIS in Education mission.

\section{METHODS}

The research aimed to assess the relationship between availability and the usage of the Pattern of GIS by University students and lecturers. A quantitative approach using survey questionnaires was applied in the study. Survey questionnaires were used as an instrument of data collection to attain the goals and objectives of this research. The population for the study consists of lecturers and students of Benue State University, Makurdi. For this study, the simple random sampling technique (Sarantakos, 2007) was used the selected one hundred and ten (110) lecturers and one thousand five hundred and seventy-nine (1579) students. Data collected from questionnaires were analysed quantitatively using the Statistical Package for Social Sciences (SPSS) 
Vol. 3, No. 1, March 2021

p-ISSN: 2656-5935 http://journal-isi.org/index.php/isi e-ISSN: 2656-4882

\section{RESULTS AND DISCUSSION}

Table 1. Results for lecturers

\begin{tabular}{|c|c|c|}
\hline \multicolumn{2}{|l|}{ Case Processing Summary (For students) } & \multirow[b]{2}{*}{ Marginal Percentage } \\
\hline Questions & & \\
\hline \multirow[t]{4}{*}{ How long have you been using ICT or GIS for learning? } & $1-5$ years & $90.2 \%$ \\
\hline & $6-10$ years & $2.4 \%$ \\
\hline & $11-15$ years & $4.9 \%$ \\
\hline & $16-30$ years & $2.4 \%$ \\
\hline \multirow[t]{2}{*}{ Do you have adequate technology infrastructure in your school? } & Yes & $95.1 \%$ \\
\hline & No & $4.9 \%$ \\
\hline \multirow[t]{2}{*}{ Do you have GIS in your school? } & Yes & $95.1 \%$ \\
\hline & No & $4.9 \%$ \\
\hline \multirow[t]{3}{*}{ Are you allowed to bring smartphones to class? } & Yes & $29.3 \%$ \\
\hline & No & $68.3 \%$ \\
\hline & Not sure & $2.4 \%$ \\
\hline \multirow[t]{3}{*}{ Is internet facility available in your school? } & Yes & $96.1 \%$ \\
\hline & No & $2.4 \%$ \\
\hline & Not sure & $2.4 \%$ \\
\hline Does your school have GIS software? & Yes & $100 \%$ \\
\hline \multirow[t]{2}{*}{ Do you have GIS software? } & Yes & $92.7 \%$ \\
\hline & No & $7.3 \%$ \\
\hline \multirow{5}{*}{$\begin{array}{l}\text { Do you know how to use the most common software (Word, Graphics, } \\
\text { Excel, Browsers, etc)? } \\
\text { Do you have the required documents such as maps and images etc to de- } \\
\text { velop GIS activities in your classes? }\end{array}$} & Yes & $97.6 \%$ \\
\hline & No & $2.4 \%$ \\
\hline & Yes & $73.2 \%$ \\
\hline & No & $24.4 \%$ \\
\hline & Not sure & $2.4 \%$ \\
\hline \multirow[t]{2}{*}{ Do you have a computer laboratory which can be used for classes? } & Yes & $92.7 \%$ \\
\hline & No & $7.3 \%$ \\
\hline \multirow{3}{*}{$\begin{array}{l}\text { It is impossible to use GIS in courses with the present insufficient infra- } \\
\text { structure in school and the background of the teachers }\end{array}$} & Yes & $75.5 \%$ \\
\hline & No & $7.3 \%$ \\
\hline & $\begin{array}{l}\text { Not sure } \\
\text { Yes }\end{array}$ & $17.1 \%$ \\
\hline $\begin{array}{l}\text { I know where to access GIS outside the school environment } \\
\text { Valid }\end{array}$ & Yes & $100 \%$ \\
\hline valla & & $100 \%$ \\
\hline
\end{tabular}

Table 2. Results for students

\begin{tabular}{|c|c|c|}
\hline \multicolumn{3}{|l|}{ Case Processing Summary (For Lecturers) } \\
\hline Questions & & Marginal Percentage \\
\hline \multirow{4}{*}{ How long have you been using ICT or GIS in your teaching? } & $1-5$ years & $40.0 \%$ \\
\hline & $6-10$ years & $40.0 \%$ \\
\hline & $11-15$ years & $10.0 \%$ \\
\hline & $>30$ years & $10.0 \%$ \\
\hline \multirow[t]{3}{*}{ Do you have the adequate technology infrastructure in your school? } & Yes & $80.0 \%$ \\
\hline & No & $10.0 \%$ \\
\hline & Not sure & $10.0 \%$ \\
\hline \multirow[t]{3}{*}{ Do you have a GIS in your school? } & Yes & $70.0 \%$ \\
\hline & No & $10.0 \%$ \\
\hline & Not sure & $20.0 \%$ \\
\hline \multirow[t]{2}{*}{ Do you bring your smartphone to class for a course that may need GIS? } & Yes & $50.0 \%$ \\
\hline & No & $50.0 \%$ \\
\hline \multirow[t]{2}{*}{ Is internet facility available in your school? } & Yes & $70 \%$ \\
\hline & No & $30.0 \%$ \\
\hline \multirow[t]{2}{*}{ Does your school have GIS software? } & Yes & $90.0 \%$ \\
\hline & Not sure & $10.0 \%$ \\
\hline \multirow[t]{2}{*}{ Do you have GIS software? } & Yes & $90.0 \%$ \\
\hline & No & $10.0 \%$ \\
\hline Do you know how to use the most common software (Word, Graphics, & Yes & $100 \%$ \\
\hline \\
\hline Do you have the required documents such as maps and images etc to de- & Yes & $70.0 \%$ \\
\hline \multirow[t]{2}{*}{ velop GIS activities in your courses? } & No & $20.0 \%$ \\
\hline & Not sure & $10.0 \%$ \\
\hline Do you have a computer laboratory which can be used for courses? & Yes & $10.0 \%$ \\
\hline It is impossible to use GIS in courses with the present insufficient infra- & Yes & $60.0 \%$ \\
\hline \multirow[t]{2}{*}{ structure in school and the background of the teachers } & No & $10.0 \%$ \\
\hline & Not sure & $80.0 \%$ \\
\hline I know where to access GIS outside the school environment & Yes & $100 \%$ \\
\hline Valid & & $100 \%$ \\
\hline
\end{tabular}




\subsection{Discussion}

- $\quad$ Length of ICT and GIS usage.

Tables 1 and 2 show that both lecturers and students have been using GIS for teaching and learning respectively. From the responses given, $80 \%$ of the lecturers indicated that they have been using ICT and GIS for the past 10 years while $90.2 \%$ of the students have been using ICT and GIS for the past 5 years. The difference in the number of years in terms of usage between the lecturers and student could be due to their age differences.

- Adequacy of technology in school.

ICT integrated learning increases students' motivation to learn (Agudo, Rico, \& Sánchez, 2016; Daungcharone, 2016; Y.-T. Luo \& Yang, 2016; Omwenga, 2016; van der Meij, van der Meij, \& Harmsen, 2015). This can only be possible if educational institutions have the adequate technology infrastructure to carry out pedagogical activities. A majority of the lecturers and students from the survey noted that they have adequate technology in their school. On the side of the lecturers, $80 \%$ of them indicated that there is adequate technology while $10 \%$ disagreed. On the other hand, $95.1 \%$ of the students noted that the university has adequate technology infrastructure while $4.9 \%$ of them disagreed.

- $\quad$ Availability of GIS

The availability of technologies in educational institutions has increased in the last couple of years (Skolverket, 2016). However, one must not consider only the availability of these innovative technologies but also its use. This is because if GIS is available and are being utilised effectively in educational institution student's retention rate and achievement will be high, while the lecturers will be presented with better techniques of delivering lectures. Responses revealed that $70 \%$ of the participating lecturers indicated that they have GIS in the school while $20 \%$ of the lecturers were not sure. $10 \%$ of the lecturers indicated that they do not have GIS in the school. This 10\% could be lecturers who noted that the school do not have adequate technology. For the students, 95.1\% of them indicated that GIS is available in their school while $4.9 \%$ disagree. This percentage of students who disagreed and the students who noted that the school does not have adequate technology.

- Use of smartphones in class.

A total of $50 \%$ of the lecturers take their smartphones to class while $50 \%$ do not. This could be because some of the lecturers may have been using their smartphones as instructional materials in other to facilitate the teaching of the course that need GIS while others may see it as a distraction. 
For the students. $29.3 \%$ indicated that they were not allowed to bring the smartphone to class while $68.3 \%$ disagreed. However, $2.4 \%$ of the students were not sure.

- Availability of internet facility.

The rationale for internet utilization for academic purposes stems from the benefits derived, such as free access to teaching and learning materials (Apuke and Iyendo 2018). Therefore, for GIS to be successfully implemented, the internet must be available. $70 \%$ of the lecturers indicated that there is internet in the school while $30 \%$ disagreed. Part of the respondents who disagreed could be among those who also indicated that there is inadequate technology in the school. On the other hand, $95.1 \%$ of the students noted that there is an internet facility in the school. While $2.4 \%$ disagree and $2.4 \%$ were not sure. The $95.1 \%$ of the students who stated that there is internet facility in the school could also be the students $(95.1 \%)$ who stated that the school has enough technology infrastructure.

- Availability and usage of GIS and other common software.

GIS integrates software and other devices to enable preparation, interpretation and presentation of spatial data (Mkhongi \& Musakwa, 2020). This means that software is an important part of GIS adoption. From the responses, all the student participants revealed that their school has GIS software while $92.7 \%$ of the students indicated that they have GIS software and that the school also has GIS software. $90 \%$ of the lecturers aligned with the students. Besides, all the lecturers agree that they know how to use the most common software such as word, excel, graphics and browsers. While $97.6 \%$ of the students indicated that they can use this software.

- Availability of documents such as data maps, and images

A total of $70 \%$ of the lecturers noted that they have the required documents such as data map and images, etc to develop the GIS activities in their courses. This $70 \%$ could be the same lecturers who indicated that they have GIS in their school. While the remaining 30\% could also be those who noted that they do not have GIS or were not sure they have GIS in their school. $73.2 \%$ of the students were also of the view that they have the required documents such as data map and images, etc to develop the GIS activities in their classes. While $24.4 \%$ disagreed.

- Availability of computer Laboratory.

It has been noted that some schools do not have computer laboratories in which students will get the chances to integrate the use of ICT to their learning 
(Ghavifekr \& Rosdy, 2015). This makes it difficult for them to enhance their learning process. Availability of computers laboratories in educational institutions also brings about equitable access to technology by students. The responses from the participants indicate that all the lecturers agree that they have computer labs in the university while $92.7 \%$ of the students aligned with them. $7.3 \%$ of the students disagreed.

- GIS versus available infrastructure.

According to Yebowaah, (2018), provision of ICT infrastructure in schools is a key strategy for promoting academic performance. Therefore, wise for educational institutions to capitalise in the benefits they can get by using these facilities by making provisions for them in the schools. Looking at the various responses, $60 \%$ of the lecturers stated that the available infrastructure in the school may not be adequate for use in GIS courses coupled with the literacy background of the lecturers in the use of technology. $10 \%$ of the lecturers disagreed while $30 \%$ of the lecturers were not sure. On the other hand, $75.5 \%$ of the students stated that the available infrastructure in the school may not be adequate for use in GIS courses coupled with the literacy background of the lecturers in the use of technology. $7.3 \%$ disagreed and $17.1 \%$ of the students were no sure.

- Accessibility of GIS outside the school environment

One benefit of technology is its ubiquity. This is a situation where technology can be accessed anytime and anywhere. This flexibility of accessing technology ubiquitously helps students to learn at their own pace and at their own time. It also helps lecturers to prepare for classes even when they are a lot in the school premises which in the end, enhances pedagogy. Looking at the responses, all the lecturers can access GIS outside the school environment. While $90.2 \%$ of the students can access GIS outside the school environment.

Testing for a relationship between the availability of GIS and usage pattern among lectures.

The null hypothesis is:

- Ho: Availability of GIS is not associated with the usage pattern among lecturers at Benue State University

and the alternate hypothesis is:

- H1: Availability of GIS is associated with the usage pattern among lectures at Benue State University

$\grave{\alpha}=0.05$

Decision rule: Reject Ho if $\mathrm{p}<0.05$ 
Vol. 3, No. 1, March 2021

p-ISSN: 2656-5935 http://journal-isi.org/index.php/isi e-ISSN: 2656-4882

Table 3. Testing for a relationship between the availability of GIS and usage pattern among lectures

\begin{tabular}{|c|c|c|c|c|}
\hline Variables & Value & $\begin{array}{l}\text { Degrees of } \\
\text { freedom }\end{array}$ & $\begin{array}{l}\text { Asymp.Sig } \\
\text { (2 sided) }\end{array}$ & Interpretation \\
\hline $\begin{array}{l}\text { Do you have adequate tech- } \\
\text { nology infrastructure in your } \\
\text { school versus Do you use GIS } \\
\text { in your school? }\end{array}$ & 42.139 & 6 & .000 & $\begin{array}{l}\text { From the values, we observe the Pearson chi-Squared } \\
\text { statistic, } x^{2}=42.139 \text { degrees of freedom } 6 \text {, corresponding } \\
\text { to } p=.000=0.05 \text {. Therefore we reject the null hypothesis } \\
\text { with } 95 \% \text { confidence and conclude that there is strong } \\
\text { evidence of an association/relationship between the two } \\
\text { variables. }\end{array}$ \\
\hline $\begin{array}{l}\text { Do you have GIS in your } \\
\text { school versus can you de- } \\
\text { velop a GIS course activity by } \\
\text { using GIS? }\end{array}$ & 45.393 & 6 & .000 & $\begin{array}{l}\text { From the values, we observe the Pearson chi-Squared } \\
\text { statistic, } x^{2}=45.393 \text { degrees of freedom } 6 \text {, corresponding } \\
\text { to } \mathrm{p}=.000<0.05 \text {. Therefore we reject the null hypothesis } \\
\text { with } 95 \% \text { confidence and conclude that there is strong } \\
\text { evidence of an association/relationship between the two } \\
\text { variables. }\end{array}$ \\
\hline $\begin{array}{l}\text { Do you bring your } \\
\text { smartphones to the class for a } \\
\text { course that may need GIS ver- } \\
\text { sus my students to use GIS in } \\
\text { their assignments and projects }\end{array}$ & 58.571 & 4 & .000 & $\begin{array}{l}\text { From the values, we observe the Pearson chi-Squared } \\
\text { statistic, } x^{2}=58.571 \text { degrees of freedom } 4 \text {, corresponding } \\
\text { to } \mathrm{p}=.000<0.05 \text {. Therefore we reject the null hypothesis } \\
\text { with } 95 \% \text { confidence and conclude that there is strong } \\
\text { evidence of an association/relationship between the two } \\
\text { variables. }\end{array}$ \\
\hline $\begin{array}{l}\text { Is internet facility available in } \\
\text { your school versus I use GIS } \\
\text { in my courses }\end{array}$ & 46.206 & 4 & .000 & $\begin{array}{l}\text { From the values, we observe the Pearson chi-Squared } \\
\text { statistic, } x^{2}=46.206 \text { degrees of freedom } 4 \text {, corresponding } \\
\text { to } p=.000<0.05 \text {. Therefore we reject the null hypothesis } \\
\text { with } 95 \% \text { confidence and conclude that there is strong } \\
\text { evidence of an association/relationship between the two } \\
\text { variables. }\end{array}$ \\
\hline $\begin{array}{l}\text { Does your school have a GIS } \\
\text { software versus I know how } \\
\text { to use GIS software? }\end{array}$ & 41.000 & 2 & .000 & $\begin{array}{l}\text { From the values, we observe the Pearson chi-Squared } \\
\text { statistic, } x^{2}=41.000 \text { degrees of freedom } 2 \text {, corresponding } \\
\text { to } \mathrm{p}=.000<0.05 \text {. Therefore we reject the null hypothesis } \\
\text { with } 95 \% \text { confidence and conclude that there is strong } \\
\text { evidence of an association/relationship between the two } \\
\text { variables. }\end{array}$ \\
\hline
\end{tabular}

Testing for a relationship between the availability of GIS and usage pattern among students.

The null hypothesis is:

- Ho: Availability of GIS is not associated with the usage pattern among students at Benue State University

and the Alternate Hypothesis is:

- H1: Availability of GIS is associated with the usage pattern among students at Benue State University $\grave{\alpha}=0.05$

Decision rule: Reject Ho if $\mathrm{p}<0.05$ 
Vol. 3, No. 1, March 2021

p-ISSN: 2656-5935 http://journal-isi.org/index.php/isi e-ISSN: 2656-4882

Table 4. Testing for a relationship between the availability of GIS and usage pattern among students

\begin{tabular}{|c|c|c|c|c|}
\hline Variables & $x^{2}$ & Df & $\begin{array}{l}\text { Asymp.Sig } \\
\text { (2 sided) }\end{array}$ & Interpretation \\
\hline $\begin{array}{l}\text { Do you have GIS software versus } \\
\text { Do you know how to use the most } \\
\text { common software (Word, Excel, } \\
\text { graphics and browser)? }\end{array}$ & .053 & 1 & .819 & $\begin{array}{l}\text { From the values, we observe the Pearson chi- } \\
\text { Squared statistic, } x^{2}=.513 \text { degrees of freedom } 1 \text {, corre- } \\
\text { sponding to } \mathrm{p}=.819>0.05 \text {. Therefore we accept the null } \\
\text { hypothesis with } 95 \% \text { confidence and conclude that there } \\
\text { is strong evidence that there is no association/relation- } \\
\text { ship between the two variables. }\end{array}$ \\
\hline Variables & $x^{2}$ & Df & $\begin{array}{l}\text { Asymp.Sig } \\
\text { (2 sided) }\end{array}$ & Interpretation \\
\hline $\begin{array}{l}\text { Do you have adequate technology } \\
\text { infrastructure in your school versus } \\
\text { do you use GIS in your classroom } \\
\text { for learning }\end{array}$ & .292 & 1 & .589 & $\begin{array}{l}\text { From the values, we observe the Pearson chi- } \\
\text { Squared statistic, } x^{2}=.292 \text { degrees of freedom } 1 \text {, corre- } \\
\text { sponding to } \mathrm{p}=.589>0.05 \text {. Therefore we accept the null } \\
\text { hypothesis with } 95 \% \text { confidence and conclude that there } \\
\text { is strong evidence that there is no association/relation- } \\
\text { ship between the two variables. }\end{array}$ \\
\hline $\begin{array}{l}\text { Do you have the required docu- } \\
\text { ments such as data, map, and images } \\
\text { etc. to develop GIS activities in your } \\
\text { classes versus } \\
\text { Do you know how to use GIS for } \\
\text { mapping? }\end{array}$ & 41.651 & 4 & .000 & $\begin{array}{l}\text { From the values, we observe the Pearson chi- } \\
\text { Squared statistic, } x^{2}=41.651 \text { degrees of freedom } 4 \text {, cor- } \\
\text { responding to } p=.000<0.05 \text {. Therefore, we reject the } \\
\text { null hypothesis with } 95 \% \text { confidence and conclude that } \\
\text { there is strong evidence of an association/relationship } \\
\text { between the two variables }\end{array}$ \\
\hline $\begin{array}{l}\text { Do you have a computer laboratory } \\
\text { which can be used for courses ver- } \\
\text { sus do you know how to use GIS for } \\
\text { any type of analysis or problem } \\
\text { solving }\end{array}$ & 3.231 & 1 & .072 & $\begin{array}{l}\text { From the values, we observe the Pearson chi- } \\
\text { Squared statistic, } x^{2}=3.231 \text { degrees of freedom } 1 \text {, corre- } \\
\text { sponding to } p=.072>0.05 \text {. Therefore, we accept the null } \\
\text { hypothesis with } 95 \% \text { confidence and conclude that there } \\
\text { is strong evidence that there is no association/relation- } \\
\text { ship between the two variables }\end{array}$ \\
\hline $\begin{array}{l}\text { I know where to access GIS outside } \\
\text { the school environment versus do } \\
\text { you use GIS outside the school en- } \\
\text { vironment }\end{array}$ & 8.154 & 1 & .004 & $\begin{array}{l}\text { From the values, we observe the Pearson chi- } \\
\text { Squared statistic, } x^{2}=8.154 \text { degrees of freedom } 4 \text {, corre- } \\
\text { sponding to } p=.004=0.05 \text {. Therefore, we reject the null } \\
\text { hypothesis with } 95 \% \text { confidence and conclude that there } \\
\text { is strong evidence of an association/relationship be- } \\
\text { tween the two variables. }\end{array}$ \\
\hline
\end{tabular}

\subsection{Discussion of findings}

GIS, being an integral part of HEIs has gone a long way to helping HEIs to solve critical problems as it aids in the provision of low-cost education, problem-solving and decision making (Mitchellet al., 2018; Fleischmann \& Van der Westhuizen, 2017; DeMers, 2016; Lehner, Jekel, \& Vogler,2017; Musakwa, 2017; Yuan, 2017). However, there are cases where this technology is available, but the usage is minimal. For instance, from the analysis in Table 4, students' responses revealed that there was no relationship between the availability of GIS software and its usage. This means that even though the GIS software was available, most students still do not know how to use it. Furthermore, the students indicated that there was adequate infrastructure, but they do not use the GIS facility often in the classrooms. The findings also revealed that there was not a relationship between the availability of computer labs in the institution and their capability of using GIS for problem-solving. 
That notwithstanding, it was also revealed from the findings that there was a correlation, according to results received from the lecturers, between having GIS in the institutions and its usage for course activities. The findings also showed that there is a correlation between the usage of smartphone in class and its usage by students in their assignments and projects. It was further revealed the availability of internet facility is associated with the use of GIS in course. This could be because for the students and lecturers to use GIS internet connectivity must be available. Conversely, findings also revealed that there is a correlation between the usage of GIS software and its availability in the institutions. Whereas on the side of the students, there were no correlations. This could mean that the lecturers are most vast in the usage of GIS software that the student.

The general view from the findings indicates that the availability of GIS infrastructure in HEIs can trigger its usage. There is also a strong need for the staff and students to be aware of this innovative technology and also be trained on its usage so that they will be able to effectively use it for their teaching and learning experience. According to Baker (2005), GIS is 'emerging as an instructional technology for supporting contextually rich student learning' as it will enable students to use maps and other databases to engage in scientific visualization.

\section{CONCLUSION}

The technological advancement of GIS has reached a new level. This is because of its ability to move to the stage of critical spatial thinking. This enables spatial issues to be learnt from a problem-based learning viewpoint, instead of a technical GIS viewpoint. However, for this to be possible, a wide range of technical abilities, skills and competences which students and lecturers need must be put into consideration. Therefore, the required intervention to develop their technical skills must not be overlooked for them to get the most from their critical spatial thinking skills and GIS applications.

The progress in the field of geographical information systems (GIS) had contributed significantly to various research that deals with measures of spatial access to educational facilities and resources. The explosive development of GIS education in developed nations should arouse the attention of developing countries towards research and rational thinking. This is because, during the next decade, the boundaries of GIS will have been pushed much further back if nothing is done. This can be seen from the responses given by the respondents where a majority of them, though can use GIS outside the school environment for other purposes, cannot use it for educational purposes.

For the future, if GIS in higher education in developing countries to be guaranteed a lot is needed to be done to achieve this. This can be in the area of creating 
awareness on its importance, making students and lecturers see the potential embedded in GIS, the introduction of GIS as an academic discipline in schools and training individuals, particularly lecturers, on the use of GIS.

\section{REFERENCES}

Agudo, J. E., Rico, M., \& Sánchez, H. (2016). Design and Assessment of Adaptive Hypermedia Games for English Acquisition in Preschool. Journal of Universal Computer Science, 22(2), 161-179

Apuke, O. and Iyendo, O. T, (2018). University students' usage of the internet resources for research and learning: forms of access and perceptions of utility. Online publication 4(12): e01052. doi: 10.1016/j.heliyon.2018.e01052

Bearman, N.; Jones, N.; Andre, I.; Cachinoh, H.A.; Demers, M. The future role of GIS education in creating critical spatial thinkers. J.Geogr. High. Educ. 2016, 40, 394-408. [CrossRef]

Barros, C. Moya-Gómez, B. Gutiérrez, J. (2020). Using geotagged photographs and GPS tracks from social networks to analyse visitor behaviour in national parks. Curr. Issues Tourism, 23 (10) (2020), pp. $1291 \quad 1310,10.1080 / 13683500.2019 .1619674$

Daungcharone, K. (2016). Using Mobile Game to Enhance the Learning Motivation and Performance in Higher Education Mobile and Wireless Technologies 2016 (pp. 215-222): Springer.

DeGrauwe, A. (2002). Improving Micro Planning in Education through a GIS: Studies on Ethiopia and Palestine. Paris: UNESCO.

Delparte, D. M., Richardson, R., Eitel, K., Matsaw, S., \& Cohn, T. (2016). Promoting Geoscience STEM Interest in Native American Students: GIS, Geovisualization and Reconceptualizing Spatial Thinking Skills. International Journal of Learning, Teaching and Educational Research, 15(5).

Fan et al., Fan, F. Chen, Y. Li, B. Liu, X. (2019) Development and testing of a new ground measurement tool to Forests, 10 (2019), p. 643, 10.3390/f10080643

Ghavifekr, S. \& Rosdy, W.A.W. (2015). Teaching and learning with technology: Effectiveness of ICT integration in schools. International Journal of Research in Education and Science (IJRES), 1(2), 175-191.

Hite, J. S. (2008). School Mapping and GIS in Educational Micro-Planning. Working Document, International Institute for Education Planning (UNESCO).

Jurado Rota, J., Pérez Albert, M.Y. Serrano Giné D. (2019). Visitor monitoring in protected areas: an approach to Natura 2000 sites using Volunteered Geographic Information (VGI). Geografisk TidsskriftDanish Journal of Geography, 119 (1) (2019), pp. 69-83, 10.1080/00167223.2019.1573409 
Kerski, J. 2008. The role of GIS in digital earth education. In ternational Journal of Digital Earth. 1(1): 326-346.

Kim et al., Thapa, S. Jang (2019). GPS-based mobile exercise application: an alternative tool to assess spatio temporal patterns of visitors' activities in a national park. Park Recreat. Adm., 37 (1) (2019), pp. 124 134, 10.18666/JPRA-2019-9175

Korpilo, S., Virtanen, T. Saukkonen, S. Lehvävirta (2018). More than A to B: understanding and managing visitor spatial behaviour in urban forests using public participation GISJ. Environ. Manag., 207 (2018), pp. $\quad$ 124-133, 10.1016/j.jenvman.2017.11.020

Lindgren, A.N. (2017). Implementation of a Volunteered Geographic Information (VGI) Mobile Application for Plant Inventory. A graduate project for the degree of Master of Science, California State University.

Louv, R. 2005. Last Child in the Woods. Algonquin Books.

Luo, Y.-F., \& Yang, S. C. (2016). The Effect of the Interactive Functions of Whiteboards on Elementary Students' Learning. Journal of Educational Computing Research, 0735633115628032

Mehmet Şeremet \& Brian Chalkley (2014): Student perspectives on the teaching of geographical information systems (GIS) in geography degrees, Journal of Geography in Higher Education, DOI: 10.1080/03098265.2014.963795

Mkhongi, F. A. and Musakwa, W. (2020). Perspectives of GIS Education in High Schools: An Evaluation of uMgungundlovu District, KwaZulu-Natal, South Africa. MDPI, Journal of Education Sciences. 10, 131; doi: 10.3390/educsci10050131.

Mitchell, M.L., (2008). Research design explained. USA: Winston, Inc.

Muñoz, L., Hausner, V. H., Monz, C.A. (2019). Advantages and limitations of using mobile apps for protected area monitoring and management. Soc. Nat. Resour., 32 (4) (2019), pp. 473-488, 10.1080/08941920.2018.1544680

NRC (National Research Council) (2006) Learning to Think Spatially. Washington: The National Academes Press.

Omwenga, E. N. (2016). Principals' Staff Motivation and its effect on ICT integration in the teaching of Science in Teacher Training Colleges. African Journal of Education and Human Development ISSN: 2518-0304, 2(1).

Pellika, \& Johnson (2005). Interactive Geographic Information System (GIS) Application for European Upper Secondary Schools.

Sarantakos, S. (2007): A toolkit for quantitative data analysis, Palgrave MacMillan, Hampshire.

Sinton, D. S., \& Bednarz, S. W. (2007). About that G in GIS. In D. S. Sinton \& J. J. Lund (Eds.), Understanding place: GIS mapping across the curriculum (pp. 19-34). Redlands, CA: ESRI Press. 
Soon S. Rathakrishnan, B. Sharif, S. Talin, R. Oliver V. (2016). The Effects of Geography Information System (GIS) Based Teaching on Underachieving Students' Mastery Goal and Achievement. The Turkish Online Journal of Educational Technology - October 2016, volume 15 Issue 4

Stonier, F., \& Hong, J. E. (2016). Bridging GIS Success. The Geography Teacher, 13(2), 52-60.

Van Der Meij, H., van der Meij, J., \& Harmsen, R. (2015). Animated pedagogical agents' effects on enhancing student motivation and learning in a science inquiry learning environment. Educational technology research and development, 63(3), 381-403.

Yebowaah, F. A., (2018). "Internet Use and its Effect on Senior High School Students in Wa Municipality of Ghana".Library Philosophy and Practice (e-journal). 1817. https:// digitalcommons.unl.edu/libphilprac/1817

Yu et al., Yu, X. Liu, B. Kong, R. Li (2019). Landscape ecology development supported by geospatial technologies: a review. Ecol. Inf., 51, pp. 185192, 10.1016/j.ecoinf.2019.03.006 